\title{
Seed-borne pathogenic fungi on some soybean varieties
}

\author{
LOEKAS SOESANTO ${ }^{1, \boldsymbol{v}}$, ANNISA RAHMADDILA RIZKY HARTONO ${ }^{1}$, ENDANG MUGIASTUTI $^{1}$, HERI WIDARTA $^{2}$ \\ ${ }^{1}$ Faculty of Agriculture, Jenderal Soedirman University, Purwokerto. Jl. Dr. Suparno, Karangwangkal, Purwokerto Utara, Banyumas 53123, Central Java, \\ Indonesia. Tel./fax.: +62-281-638791, vemail: lukassusanto26@ gmail.com \\ ${ }^{2}$ Agricultural Quarantine Institute Class I Semarang. J1. Moh. Pardi No.7, Tanjung Mas, Semarang 50174, Central Java, Indonesia
}

Manuscript received: 17 July 2020. Revision accepted: 8 August 2020.

\begin{abstract}
Soesanto L, Hartono ARR, Mugiastuti E, Widarta H. 2020. Seed-borne pathogenic fungi on some soybean varieties. Biodiversitas 21: 4010-4015. The present study was conducted to detect and identify seed-borne pathogenic fungi in some soybean varieties and their effect on seed germination. Experiment was performed in a completely random design with eight treatments and four replicates. Eight soybean varieties i.e., Malabar, Kaba, Dering, Detam I, Sinabung, Dena, Gepak Kuning, and Slamet were selected for the investigation. Seed borne fungi were isolated using blotter test and agar plate techniques. The variables observed were morphological/cultural characteristics, microscopic features of fungi, and percentage of seed germination. A total of eight fungi namely Aspergillus flavus Link, Aspergillus niger van Tieghem, Cladosporium oxysporum Berk. \& M.A. Curtis, Colletotrichum dematium (Pers. et Fr.) Grove f.sp. truncate (Schw.) Arx, Curvularia pallescens Boedijn, Fusarium solani (Mart.) Sacc., Melanospora zamiae Corda, and Nigrospora sp. Mason were isolated from different varieties of soybean seeds. The highest seed germination was found to be $80.5 \%$ in Daring and Detam I varieties, respectively, and the lowest 53\% was recorded in Dena variety.
\end{abstract}

Keywords: Identification, seed-borne pathogenic fungi, seed germination, soybean

\section{INTRODUCTION}

Soybean (Glycine $\max$ L. Merril) is the third most important food commodity after rice and corn (Bowo et al. 2016). Soybean is one of the government's priorities because it produces vegetable proteins that contain significant nutritional content, is safe for consumption, and its price is relatively cheap compared to other protein sources, such as meat, milk, and fish (Sharma et al. 2014). However, soybean production during the last 6 years (2011-2017) in Indonesia, especially in East Java, decreased by $7.16 \%$ and $45.25 \%$ respectively (BPS 2018). This makes Indonesia a soybean importer (Ningrum et al. 2018).

. Attack of plant pathogens is one of the reasons for low soybean productivity and 55 fungal species has been isolated from soybean seeds. The most frequent genera were Alternaria, Diaphorte, and Fusarium (Escamilla et al. 2019). Certified seeds do not guarantee to be free from seed-borne pathogens (Bishaw et al. 2013). Infected seeds can directly affect plant growth and become a source of infection in the field (Pérez-Pizá et al. 2019). . Healthy seeds are one reason for increasing crop production. Inspection of seed quality, physiological and pathological health is absolutely necessary as seeds can be carriers of plant diseases (Dutta et al. 2014; Sharma et al. 2015). Diseasetransmitted seeds can affect seed germination, mortality in the nursery stage, and the development of disease at the younger stage. The impact on farmers is economic loss, because maintenance and labor costs are not comparable with declining production yields (Dutta et al. 2014).

Pathogens can be found in seeds before or after germination (Garuba et al. 2014). Seed-borne pathogens are agents that are found internally or externally in seeds and have the potential to cause diseases in plants (Gupta et al. 2017; Pedraza et al. 2018). Several pathogenic fungi like Rhizopus, Alternaria, Culvularia, Diaporthe, Mucor, Corynespora, Cercospora, Colletotrichum, Phoma, Pythium, Fusarium, Aspergillus, and Cladosporium have been isolated from soybean seeds (Saylendra and Fatmawaty 2010; Kinnikar et al. 2015; Escamilla et al. 2019).

Seed is the most easily planted part mainly for trade. Seed-borne diseases can be spread through insects, water, wind, agricultural equipment, and transportation. These activities need to be monitored to avoid transmission of disease from seeds to plants (Dutta et al. 2014). Therefore, the aim of the study is to identify pathogenic fungi in several soybean varieties and to investigate their effect on seed germination.

\section{MATERIALS AND METHODS}

\section{Sample collection}

Eight different varieties of soybean i.e. Malabar, Kaba, Ring, Detam 1, Sinabung, Dena, Yellow Gepak, and Slamet were collected from the Laboratory of Plant Breeding, Jenderal Soedirman University. The seed samples were brought to the laboratory and stored at room temperature for subsequent studies.

\section{Isolation of fungi on blotter test}

Four-hundreds (400) soybean seeds per variety were selected for the blotter test. Surface of soybean seeds was sterilized by immersing in sodium hypochlorite solution (1\%) for $3 \mathrm{~min}$. and rinsed with distilled water. Soybean seeds are put into a Petri dish which contains 3 sheets of 
sterile filter paper that have been moistened with sterile aquadest. In this method, three pieces of filter paper were soaked in sterilized distilled water and placed on the bottom of the petri dish. Soybean seeds were taken randomly from each variety and then placed on moist filter paper. The Petri dishes were then incubated at room temperature $\left( \pm 26^{\circ} \mathrm{C}\right)$ for 7 days. The growth of fungus was observed on $8^{\text {th }}$-day using stereomicroscope and compound microscopy. In addition, the percentage of seed germination was also observed (de Camargo et al. 2017).

\section{Isolation of fungi on agar plate}

40 soybean seeds per variety were used for the agar plate. Soybean seeds were sterilized with $70 \%$ alcohol for 30 seconds, followed by $1 \% \mathrm{NaOCl}$ for 3 minutes and then washed with sterile distilled water. The seeds were placed into a petri dish containing PotatoDextrose Agar (200 g of potato extract, $18 \mathrm{~g}$ of agar, $20 \mathrm{~g}$ of dextrose, and $1000 \mathrm{~mL}$ of distilled water), 10 seeds per petri dish and then incubated for 7 days at room temperature. A pure culture of each fungus was maintained on PDA for identification purposes (Wain-Tassi et al. 2012).

\section{Fungal identification}

Isolated fungal species were identified on the basis of their gross colony morphology (shape, size, and color of colony) and microscopic feature (characteristics of mycelium, shape, size and color of conidia and conidiophores, setae, etc.) as described by (Benoit and Mathur 1970; Ellis 1971; Domsch et al. 1980; Watanabe 2002; Gaddeyya et al. 2012; Alsohaili and Bani-Hasan 2018; Amteme and Tefa 2018).

\section{Seed germination $(\%)$}

The percentage of seed germination was calculated by applying the formula of ISTA (1996):
Seed germination $(\%)=($ Number of seed germinated $) /$ (Number of total seeds) $\times 100$

\section{Data analysis}

Seed germination was analyzed using the $\mathrm{F}$ test with a confidence level of $95 \%$ and further tested with a HSD level of $5 \%$.

\section{RESULTS AND DISCUSSION}

\section{Isolation and identification of seed-borne pathogenic fungi}

Results of (Table 1) blotter test method showed that all the eight varieties of soybean were infected with seed born pathogenic fungi. Fungi were found to colonize in the tested seeds. A total of eight fungal species namely Aspergillus flavus Link, Aspergillus niger van Tieghem, Cladosporium oxysporum Berk. \& M.A. Curtis, Colletotrichum dematium (Pers. Et Fr.) Grove f.sp. truncate (Schw.) Arx, Curvularia pallescens Boedijn, Fusarium solani (Mart.) Sacc., Melanospora zamiae Corda, and Nigrospora sp. Mason were isolated from soybean seeds.

Based on Tables 1 and 2, it can be seen that more fungi were obtained in the blotter test than PDA. The blotter test method can detect pathogenic fungi found on the surface of seed. A total of eight fungi were isolated by the blotter test and only four fungi were isolated by PDA. Rao et al. (2015), reported that blotter test detected more fungi than agar plate. Pathak and Zaidi (2013) stated that blotter method was found to be the best method for the isolation of mycoflora whether borne externally or internally. In general, on both blotter methods and PDA significantly difference among soybean varieties were found for fungal isolates.

Table 1. Fungi isolated from different varieties of soybean seeds by blotter test

\begin{tabular}{|c|c|c|c|c|c|c|c|c|}
\hline Fungi & Ml & $\mathbf{K b}$ & Dr & Dt & Sn & Dn & Gk & Sl \\
\hline Aspergillus flavus & + & + & - & - & + & + & - & + \\
\hline Aspergillus niger & - & - & - & - & + & - & - & - \\
\hline Cladosporium oxysporum & + & + & + & + & + & + & + & + \\
\hline Colletotrichum dematium & - & - & + & + & - & - & + & - \\
\hline Curvularia pallescens & + & - & + & + & - & - & - & + \\
\hline Fusarium solani & + & + & + & + & + & + & + & + \\
\hline Melanospora zamiae & - & - & - & - & - & - & - & + \\
\hline Nigrospora sp. & - & + & - & - & - & - & - & - \\
\hline
\end{tabular}

Note: +: found, -: not found, Ml: Malabar, Kb: Kaba, Dr: Dering, Dt: Detam I, Sn: Sinabung, Dn: Dena, Gk: Gepak Kuning, Sl: Slamet

Table 2. Fungi isolated from different varieties of soybean seeds by PDA

\begin{tabular}{lcccccccc}
\hline Fungi & Ml & Kb & Dr & Dt & Sn & Dn & Gk & Sl \\
\hline Aspergillus niger & - & - & - & - & - & - & - & + \\
Cladosporium oxysporum & - & + & - & - & - & + & - & - \\
Colletotrichum dematium & - & - & - & - & + & - & - & - \\
Fusarium solani & + & - & + & + & - & - & + & + \\
\hline Note: +: found, -: not found, Ml: Malabar, Kb: Kaba, Dr: Dering, Dt: Detam I, Sn: Sinabung, Dn: Dena, Gk: Gepak Kuning, Sl: Slamet
\end{tabular}


Tables 1 and 2 showed that the most common seedborne fungi were found in the Slamet variety. It is assumed that Slamet variety has vertical resistance (qualitative) that is organized by one gene and only to several types of pathogens. Varieties with vertical resistance are easily infected with new pathogens. Based on Nelson (2003), vertical resistance is usually inherited by a single gene or a number of genes. Local varieties have horizontal resistance known as quantitative resistance as a type of resistance that is resistant to all types of pathogens. Horizontal resistance varieties show little sensitivity to pathogens, but have the ability to slow the rate of disease progression. Cladosporium oxysporum and Fusarium solani were recorded as the dominant fungal species on blotter test and PDA (Tables 1 and 2). Kinniker et al. (2015) reported that the pathogenic genus Cladosporium and Fusarium often infected the soybean seeds. The morphological characteristics of the seed-borne pathogenic fungus are as follows.

\section{Aspergillus flavus Link}

Aspergillus flavus was found in Malabar, Kaba, Sinabung, Dena, and Slamet varieties. Macroscopically, A. flavus colonies were yellowish-green, rough conidium structure, and granular in shape (Figure 1.A). Praja and Yudhana (2017) observed that colonies of A. flavus were first white and then finally turn into yellowish-green color. The reverse side showed yellowish to brown color. A. flavus has a rounded shape with a flat edge (Mathur and Kongsdal 2003). Mycelia was in the form of fine threads (Hameed et al. 2012; Krijgsheld et al. 2013).

Microscopically, A. flavus has a hypha that was insulated, fialid, metula, erectile conidiophores, colorless, and has foot cells (Figure 1.B). According to Procop et al. (2016), A. flavus has hyphae insulated, erectile conidiophores, unbranched, colorless, the edges form round vesicles that carry conidia. Conidiophores were clear, rough, not pigmented, and less than $1 \mathrm{~mm}$ long (Gautam and Bhadauria 2012).

\section{Aspergillus niger van Tieghem}

Aspergillus niger found in Sinabung and Slamet varieties. Macroscopically, A. niger colonies were black with white edges and spread (Figure 2.A). According to Koneman (1979) and Praja and Yudhana (2017), A. niger has black colony with white edges, the lower surface of the colonies was yellowish to brown.

Conidia were spherical and black in color. Vesicles were spherical, and conidiophores were colorless (Figure 2.B). The A. niger fungus has a visibly cotton-like filamentous called hyphae, has a large, rounded carrier head, black conidia, with conidiophores that contain many pigments (Chang et al. 2020). Walsh et al. (2018), Mathur and Kongsdal (2003), Gautam et al. (2011), and Wangge et al. (2012) resulted in long and colorless vesicles, round to semi-round vesicles, conidia round to semi-round and brown to black.

\section{Cladosporium oxysporum Berk. \& M.A. Curtis}

Cladosporium oxysporum was found in all soybean varieties. The colonies of $C$. oxysporum were white to grayish brown to blackish-green color and shaped like cotton-like to velvet shape (Figure 3.A). Briceño and Latorre (2007) and Guan et al. (2016) stated that $C$. oxysporum has light green brownish to blackish-green colony, and growth is relatively slow.

Microscopic observation of the $C$. oxysporum has an elliptical conidium, one of the ends is tapered and there are black spots, sometimes there is a divider (Figure 3.B). Based on Lamboy and Dillard (2007), the microscopic features of $C$. oxysporum are hyphae that are insulated, conidiophores are lateral or terminal in hyphae, conidia are chain-shaped and smooth-walled. An elliptical conidium is found in a branched-chain. The $C$. oxysporum has a small colony that is blackish green and pollinated (Figure 3b). Spores develop at the ends of complex conidiophores that grow from one insulated mycelium. Usually brownish.

\section{Colletotrichum dematium (Pers. et Fr.) Grove f.sp. truncata} (Schw.) Arx.

The fungus $C$. dematium is found in the Ringer, Detam I, Sinabung and Gepak Kuning varieties. Macroscopically a single aservulus colony and / or group, sometimes fused, aservulus blackish-brown was observed (Figure 4.A). Based on Soesanto (2015), C. dematium fungus has a dark aservulus and develops on patches in the host tissue.

Acervulus of $C$. Dematium has 1-4 bulkhead, blackishbrown color and, its size was longer than conidia. Conidia were hyaline, curved with pointed ends (Figure 4B.). According to Haggag and Singer (2013), C. dematium colonies form concentric rings, curved conidia with tapered ends, and setae. Hyphae were brown in color, 3-4 septate. Setae were dark brown in color. Curvularia pallescens Boedijn

\section{Curvularia pallescens Boedijn}

Curvularia pallescens found in Malabar, Dering, Detam I, and Slamet varieties. Macroscopically the $C$. pallescens spread and form like feathers (Figure 5.A). According to Hoog et al. (2001), C. pallescens has a scattered, hairy colony in the middle, often developing concentric zones.

Conidia of $C$. pallescens was light brown to brown, mostly straight and slightly curved, has 3 baffles and 4 cells, the third cell was larger than other cells (Figure 5.B). Hoog et al. (2001), stated that conidia can look slightly bent but mostly straight. The conidia has 3 septae giving rise to 4 cells. The third cell from the base looks swollen compared to the cells around it. Its texture looks smooth and pale brown to brown (Dey et al. 2016).

\section{Fusarium solani (Mart.) Sacc.}

Fusarium solani found in all varieties, namely Malabar, Kaba, Dering, Detam I, Sinabung, Dena, Yellow Gepak, and Slamet. F. solani has white to creamy mycelium, clumping like a thick cloud, and droplets were found on the surface of the colony (Figure 6.A). Similar observations were reported by Hafizi et al. (2013). 


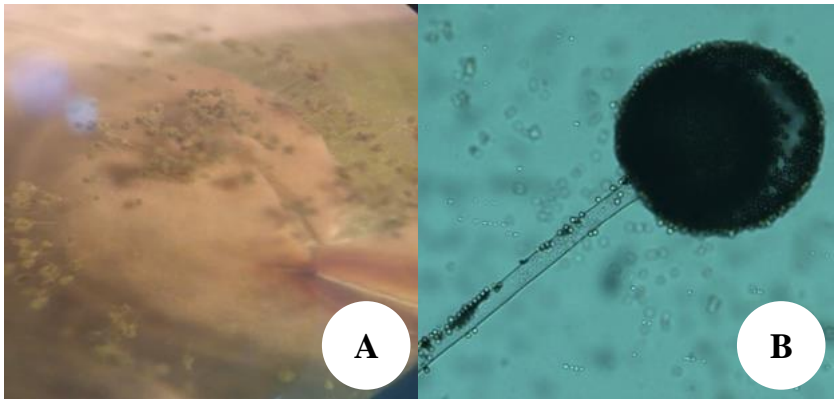

Figure 1. Macroscopic and microscopic Aspergillus flavus. A. A. flavus colony at 50x magnification; B. Vesicle and conidia of $A$. flavus at 400x magnification

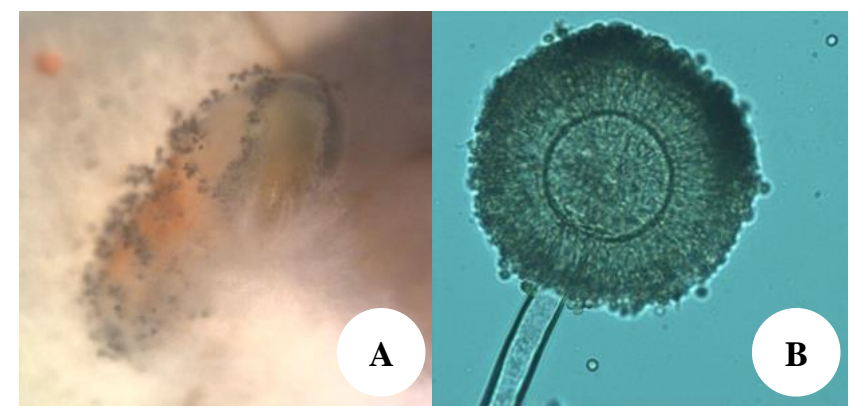

Figure 2. Macroscopic and microscopic Aspergillus niger. A. A. niger colony at magnification $30 \mathrm{x} ; \mathrm{B}$. Vesicle and conidia of $A$. niger magnification at $400 \mathrm{x}$

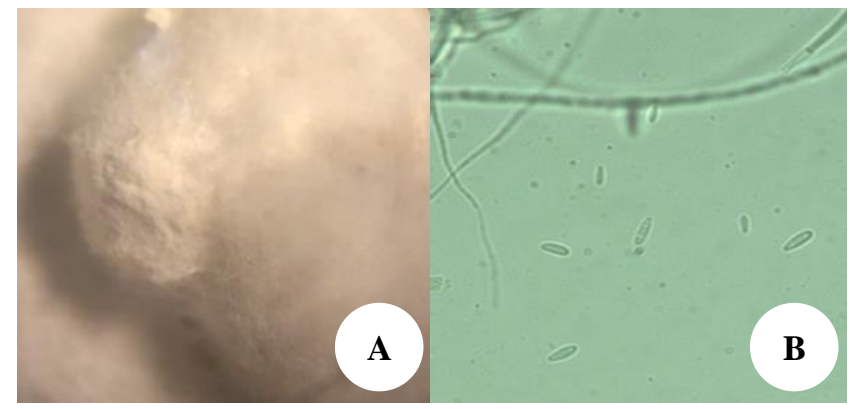

Figure 3. Macroscopic and microscopic Cladosporium oxysporum. A. C. oxysporum colony at 30x magnification; B. Conidia at 400x magnification

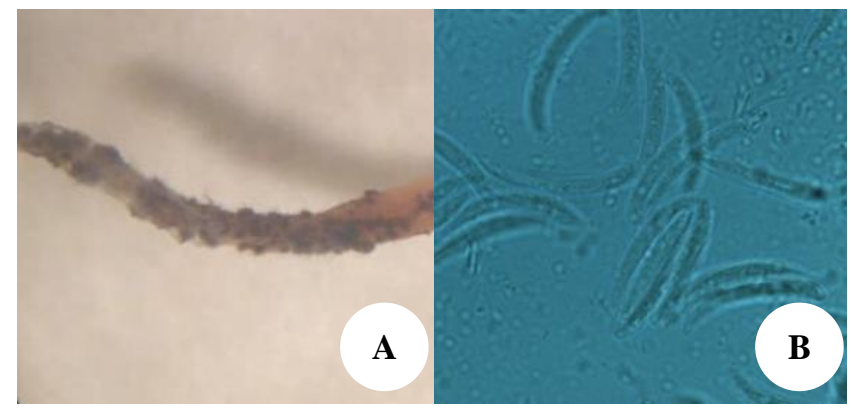

Figure 4. Macroscopic and microscopic Cladosporium dematium. A. C. dematium colony at $30 \mathrm{x}$ magnification; B. Conidia at 1000x magnification

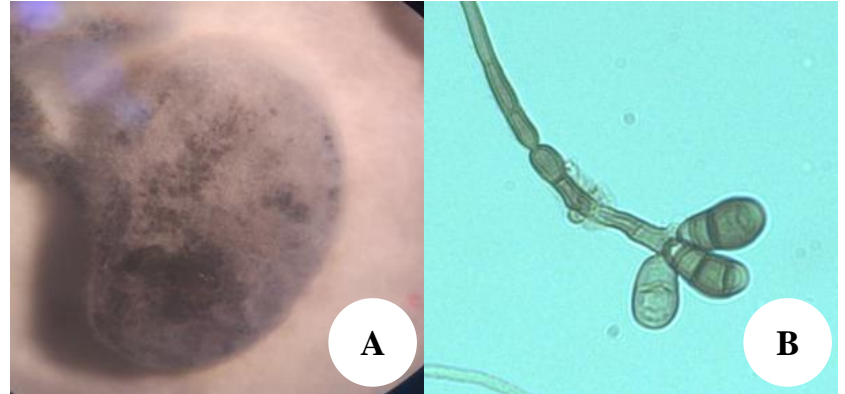

Figure 5. Macroscopic Curvularia pallescens. A. C. pallescens colony at 30x magnification; B. C. pallescens conidia at 400x magnification

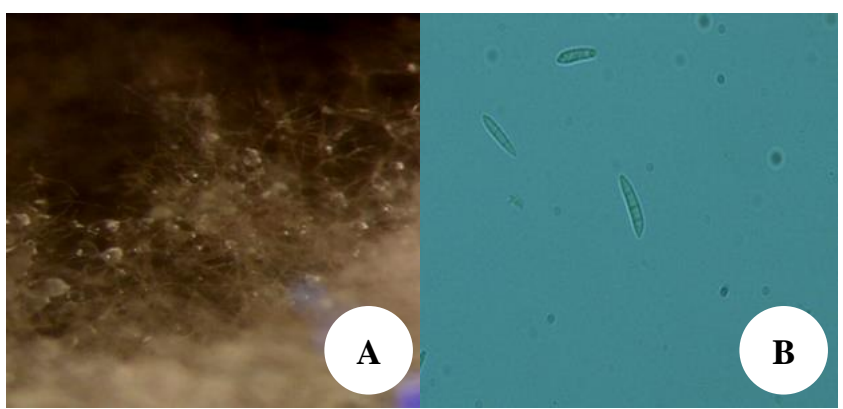

Figure 6. Macroscopic and microscopic Fusarium solani. A. F. solani colony magnification at $63 \mathrm{x}$ magnification; B. F. solani conidia at $400 x$ magnification

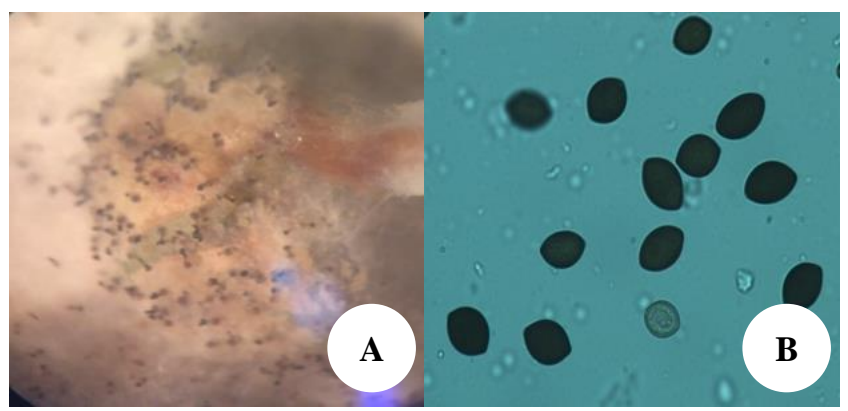

Figure 7. Macroscopic and microscopic Melanospora zamiae. A. Colony of $M$. zamiae at 30x magnification; B. conidia at 400x magnification

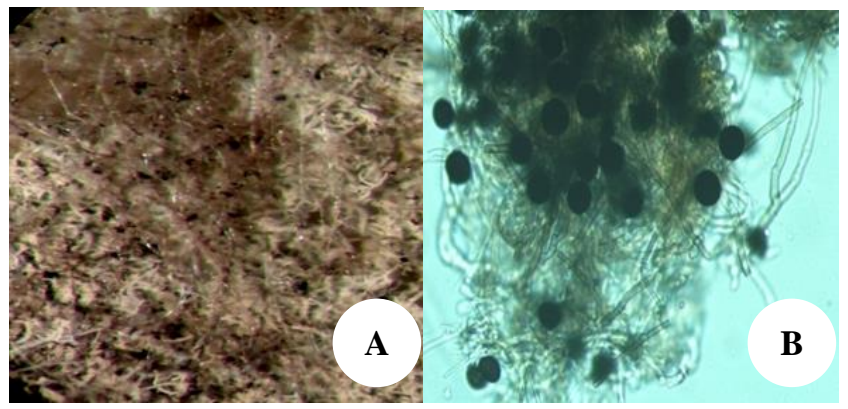

Figure 8. Macroscopic and microscopic Nigrospora sp. A. Nigrospora $\mathrm{sp}$. at 50x magnification; B. Nigrospora $\mathrm{sp}$. Conidia 400x magnitude. 
In $F$. solani microconidia were 1-2 celled, colorless, and oval shape. Macroconidia had 3-4 septa and colorless (Figure 6.B). Based on research by Hafizi et al. (2013) reported that in single-cell microconidia were oval to kidneyshaped while, macroconidia were thick-walled, generally cylindrical with dorsal ends and ventral edges parallel.

\section{Melanospora zamiae Corda}

Melanospora zamiae found only in Slamet variety. the fungal colony is yellow and has a neck, black colony (Figure 7.A). According to Mathur and Kongsdal (2003), $M$. zamiae has a superficial perithecium fungus, light white to golden yellow, translucent, round with short to long necks. dark mass, containing ascospores usually seen flowing from the neck.

Microscopically the conidia were lemon-shaped, brown to almost black color (Figure 7.B). According to Mathur and Kongsdal (2003), M. zamiae has ascopores of lemonshaped (citriform) and dark brown to almost black color.

\section{Nigrospora sp. Mason.}

Nigrospora sp. was found only in the Kaba variety. Blackish gray mycelium (Figure 8.A). Hao et al. (2020) reported that Nigrospora sp. has brownish-gray colonies with white edges, solid surface texture and rounded colonies. It has a hypha insulated and colorless, single conidia, round in shape, and deep black or not transparent (Figure 8.B). According to Hao et al. (2020), Nigrospora sp. has colorless conidiophores and insulated hyphae, conidia were black and unicellular.

\section{Seed germination ability}

From Table 3, germination rate of soybean seeds was found to be different in each variety. The highest seed germination was found in the Dering and Detam I soybean varieties as $80.5 \%$, respectively, and the lowest one was found in Dena variety as 53\%. The highest $(80.5 \%)$ seed germination was found in the Daring and Detam I varieties and the lowest (53\%) was found in Dena variety.

Based on Table 3, Dering and Detam I varieties was classified as high seed germination varieties. Whereas, Sinabung, Dena, Gepak Kuning, and Slamet varieties were classified as low seed germination varieties. The statement is in accordance with the germination standard which is classified as high for almost all seeds if the results of the seed germination test showed a value of $\geq 80 \%$ (Rahayu and Suharsi 2015).

Table 3. Percentage of seed germination in various varieties

\begin{tabular}{lc}
\hline Varieties & Seed germination $(\%)$ \\
\hline Malabar & $79.0 \mathrm{~d}$ \\
Kaba & $78.0 \mathrm{~d}$ \\
Dering & $80.5 \mathrm{~d}$ \\
Detam & $80.5 \mathrm{~d}$ \\
Sinabung & $68.5 \mathrm{c}$ \\
Dena & $53.0 \mathrm{a}$ \\
Gepak Kuning & $71.5 \mathrm{c}$ \\
Slamet & $59.5 \mathrm{~b}$ \\
\hline
\end{tabular}

Note: Number followed by different letters in the same column show significantly different from HSD at the 5\% level.
Although 4 pathogenic fungi infected Daring and Detam I varieties (Tables 1 and 2), still these varieties showed the highest percentage of seed germination (Table 3). It can be suspected that these two varieties have horizontal resistance so that they were able to withstand the attack of pathogenic fungi. Penfield and MacGregor (2017) state that the percentage of seed germination has been affected by many factors including pathogen attack, genetic factors, and the environment.

Dena variety has the lowest germination rate (Table 3), but associated with 3 fungi (Tables 1 and 2). It was suspected that the Dena variety was frequently planted as 2-3 times resulted in decreasing germination compared to the first planting. Another factor that can trigger low seed germination capacity is uneven imbibition of the seed so that the growth of the seed becomes non-synchronized normal sprouts (Rahayu and Suharsi 2015).

The emergence of many pathogenic fungi may be caused by unsterile conditions of the germination substrate, seed germination tool, storage, and water used. Ghangaokar and Kshirsagar (2013) suggested that seed-borne microbes mostly found in those seeds that do not receive seed treatment. Due to microbial infestation, plant vigor and seed germination capacity decreases.

In conclusion eight pathogenic fungi namely, Aspergillus flavus, A. niger, Cladosporium oxysporum, Curvularia pallescens, Fusarium solani, Melanospora zamiae, and Nigrospora sp. were found to be associated with soybean seeds. The Daring and Detam I varieties showed highest $(80.5 \%$ each) seed germination while lowest $(53 \%)$ was found in Dena variety.

\section{REFERENCES}

Amteme K, Tefa A. 2018. Identification of pathogenic fungi on several rice seeds based on storage model. Portal Jurnal Unimor 3 (1): 4-7. [Indonesian]

Alsohaili SA, Bani-Hasan BM. 2018. Morphological and molecular identification of fungi isolated from different environmental sources in the northeastern desert of Jordan. Jordan J Biol Sci 11 (3): 329-337.

BPS [Badan Pusat Statistik]. 2018. Harvest area, Productivity, and Production of Soybean at East Java. http://jatim.bps.go.id/statictable/2018/10/31/1342/luas-panenproduktivitas-dan-produksi-kedelai-di-jawa-timur-2002-2017

Benoit MA, Mathur SB. 1970. Identification of Species of Curvularia on Rice Seed. Proc. Int. Seed Test. Ass., Switzerland.

Bishaw Z, Struik PC, van Gastel AJG. 2013. Farmer's seed sources and seed quality: 2. seed health. Intl J Plant Prod 7 (4): 637-657.

Bowo P, Nurayati A, Imleesh RM. 2016. Analysis of competitiveness and government policy on rice, corn and soybean farming. .JEJAK:Jurnal $\begin{array}{lllll}\text { Ekonomi dan } & \text { Kebijakan } 9 & \text { (2): }\end{array}$ DOI:10.15294/jejak.v9i2.8235. [Indonesian]

Briceño EX, Latorre BA. 2007. Outbreaks of Cladosporium rot associated with delayed harvest wine grapes in Chile. Plant Dis. 91 (8): 1060. DOI: 10.1094/PDIS-91-8-1060C.

Chang PK, Cary JW, Lebar MD. 2020. Biosynthesis of conidial and sclerotial pigments in Aspergillus species. Appl Microbiol Biotechnol 104 (3): 2277-2286. DOI: 10.1007/s00253-020-10347-y.

de Camargo MP, de Moraes MHD, Menten JOM. 2017. Efficiency of blotter test and agar culture medium to detect Fusarium graminearum and Pyricularia grisea in wheat seeds. J Seed Sci 39 (3): 297-302. DOI: 10.1590/2317-1545v39n3168931.

Dey D, Saha B, Sircar G, Ghosal K, Bhattacharya SG. 2016. Mass spectrometry-based identification of allergens from Curvularia pallescens, a prevalent aerospore in India. Biochimica et Biophysica 
$\begin{array}{lllll}\text { Acta Proteins Proteomics } 1864 & \text { (7): } 869-879 . \quad \text { DOI: }\end{array}$ 10.1016/j.bbapap.2016.03.012.

Domsch KH, Gams W, Anderson TH. 1980. Compendium of Soil Fungi. Academic Press, New York.

Dutta B, Gitaitis R, Smith S, Langston Jr D. 2014. Interactions of seedborne bacterial pathogens with host and non-host plants in relation to seed infestation and seedling transmission. PLoS ONE 9 (6): e99215. DOI: 10.1371/journal.pone.0099215.

Ellis MB. 1971. Dematiaceous Hyphomycetes. Commonwealth Mycological Institute. England.

Escamilla D, Rosso ML, Zhang B. 2019. Identification of fungi associated with soybeans and effective seed disinfection treatments. Food Sci Nutr 7 (10): 3194-3205. DOI: 10.1002/fsn3.1166.

Gaddeyya G, Niharika PS, Bharathi P, Kumar PKR. 2012. Isolation and identification of soil mycoflora in different crop fields at Salu Mandal. Adv Appl Sci Res 3 (4): 2020-2026.

Garuba T, Abdulrahaman AA, Olahan GS, Abdulkareem KA, Amadi JE. 2014. Effects of fungal filtrates on seed germination and leaf anatomy of maize seedlings (Zea mays L., Poaceae). J Appl Sci Environ Manage 18 (4): 662-667. DOI: 10.4314/jasem.v18i4.15.

Gautam AK, Bhadauria R. 2012. Characterization of Aspergillus species associated with commercially stored Triphala powder. Afr J Biotechnol 11 (104): 16814-16823.

Gautam AK, Sharma S, Avasthi S, Bhadauria R. 2011. Diversity, pathogenicity and toxicology of A. niger: An important spoilage fungi. Res J Microbiol 6: 270-280. DOI: 10.3923/jm.2011.270.280.

Ghangaokar NM, Kshirsagar AD. 2013. Study of seed-borne fungi of different legumes. Sci J 2 (1):32-35.

Guan G-Q, Zhao P-X, Zhao J, Wang M-J, Huo S-H, Cui F-J, Jiang J-X 2016. Production and partial characterization of an alkaline xylanase from a novel fungus Cladosporium oxysporum. Bio Med Res Intl 2016: 4575024. DOI: $10.1155 / 2016 / 4575024$

Gupta S, Dubey A, Singh T. 2017. Fusarium semitectum as a dominant seed-borne pathogen in Albizzia lebbeck (Linn.) Benth., its effect on location and transmission studies. Res J For 11: 13-18. DOI 10.3923/rjf.2017.13.18

Hafizi R, Salleh B, Latiffah Z. 2013. Morphological and molecular characterization of Fusarium solani and $F$. oxysporum associated with crown disease of oil palm. Brazilian J Microbiol 44 (3). DOI 10.1590/S1517-83822013000300047

Haggag WM, Singer S. 2013. First report of Colletotrichum capsici causing pre and postharvest anthracnose on papaya in Egypt. Intl J Eng Innov Technol 3 (6): 151-152.

Hameed AAA, Ayesh AM, Mohamed MAR, Mawla HFA. 2012. Fungi and some mycotoxins producing species in the air of soybean and cotton mills: a case study. Atmos Poll Res 3 (1): 126-131. DOI: 10.5094/APR.2012.012.

Hao Y, Aluthmuhandiram JVS, Chethana KWT, Manawasinghe IS, Li X, Liu M. 2020. Nigrospora species associated with various hosts from Shandong Peninsula, China. Mycobiol 48 (3): 169-183. DOI: 10.1080/12298093.2020.1761747.

Hoog GSde, Guarro J, Gene J, Figueras MJ. 2001. Atlas of Clinical Fungi (2nd ed.). American Society for Microbiology, USA.

ISTA. 1996. International Rules for Seed Testing, Rules 1996. International Seed Testing Association (ISTA). Seed Science and Technology 24 (supplement). Zurich. Switzerland.

Kinnikar A, Desai P, Jahagirdar S. 2015. Identification and detection of seed-borne diseases of soybean using image processing-a survey. Intl J Emerg Technol Comput Sci Electr 14 (2): 363-368.

Koneman EW. 1979. Practical Laboratory Mycology, 2nd ed. The Williams and Wilkins Co. USA.

Krijgsheld P, Bleichrodt R, van Veluw GJ, Wang F, Müller WH, Dijksterhuis J, Wösten HAB. 2013. Development in Aspergillus. Stud Mycol 74 (1): 1-29. DOI: 10.3114/sim0006.

Lamboy JS, Dillard HS. 2007. First report of a leaf spot caused by Cladosporium oxysporum on greenhouse tomato. Plant Dis 81 (2): 228. DOI: 10.1094/PDIS.1997.81.2.228D.
Machowicz-Stefaniak Z. 2010. Occurrence and characterization of Colletotrichum dematium (Fr.) Grove. Polish J Microbiol 59 (3): 191200.

Mathur SB, Kongsdal O. 2003. Common Laboratory Seed Health Testing Methods for Detecting Fungi. International Seed Testing Association. Bassedorf, Switzerland.

Navi SS, Singh SD, Lenne JM, Kirk PM, Brayford D. 1999. New grain mold fungi of sorghum in India. J Mycol Plant Pathol 27: 104-105.

Nelson RR. 2003. Genetics of horizontal resistance to plant diseases. Ann $\begin{array}{lllll}\text { Rev Phytopathol } 16 & \text { (1): } 359-378 . & \text { DOI: }\end{array}$ 10.1146/annurev.py.16.090178.002043.

Ningrum IH, Irianto H, Riptanti EW. 2018. Analysis of soybean production and import trends and its import factors in Indonesia. IOP Conf Ser Earth Environ Sci 14: 012059. DOI: 10.1088/1755$1315 / 142 / 1 / 012059$

Pathak N, Zaidi RK. 2013. Studies on seed-borne fungi of wheat in seed health testing programme. Archives of Phytopathol and Plant Protection 46 (4): 389-401. DOI: 10.1080/03235408.2012.741978.

Pedraza LA, Bautista J, Uribe-Vélez D. 2018. Seed-born Burkholderia glumae infects rice seedling and maintains bacterial population during vegetative and reproductive growth stage. Plant Pathol J 34 (5): 393402. DOI: 10.5423/PPJ.OA.02.2018.0030

Penfield S, MacGregor DR. 2017. Effects of environmental variation during seed production on seed dormancy and germination. J Exp Bot 68 (4): 819-825. DOI: 10.1093/jxb/erw436.

Pérez-Pizá MC, Prevosto L, Grijalba PE, Zilli CG, Cejas E, Mancinelli B, Balestrasse KB. 2019. Improvement of growth and yield of soybean plants through the application of non-thermal plasmas to seeds with different health status. Heliyon 5 (4): e01495. DOI: 10.1016/j.heliyon.2019.e01495.

Praja RN, Yudhana A. 2017. Isolation and identification of Aspergillus spp. on lung chicken for sale at Banyuwangi Market. Jurnal Medik Veteriner 1 (1): 6-11.

Procop GW, Church DL, Janda WM, Koneman EW, Schreckenberger PC, Woods GL. 2016. Color Atlas and Textbook of Diagnostic Microbiology, $7^{\text {th }}$ ed. Wolters Kluwer. Australia.

Purnawati F. 2015. Identification, level of attack, and the potential to carry Colletotrichum sp. seeds in cucumber (Cucumis sativus L.). [Thesis] Institut Pertanian Bogor, Bogor. [Indonesian]

Rahayu AD, Suharsi TK. 2015. Observation of germination test and optimization of winged (Psophocarpus tetragonolobus L.) seed germination substrate. Buletin Agrohorti 3 (1): 18-27.

Rao TV, Rajeswari B, Keshavulu K, Varma VS. 2015. Studies on seedborne fungi of soybean. SSRG Intl J Agric Environ Sci 2 (1): 16-24.

Saylendra A, Fatmawaty A. 2010. Identification of microbes carried by soybean seed varieties of Galunggung, Wilis, dan Anjasmoro. Jurnal Agroekoteknologi 2 (1): 27-30. [Indonesian]

Sharma D, Gupta R, Joshi I. 2014. Nutrient analysis of raw and processed soybean and development of value-added soybean noodles. Invent Rapid Life Style 2014 (1): 1-5.

Sharma KK, Singh US, Sharma P, Kumar A, Sharma L. 2015. Seed treatments for sustainable agriculture-A review. J Appl Nat Sci 7 (1): 521-539.

Soesanto L. 2015. Compendium of Soybean Diseases. Bumi Aksara. Jakarta. [Indonesian].

Wain-Tassi AL, dos Santos JF, de Cássia Panizzi R, Vieira RD. 2012. Seed-borne pathogens and electrical conductivity of soybean seeds. Scientia Agricola (Piracicaba, Braz.) 69 (1) 19-25. DOI: 10.1590/S0103-90162012000100004.

Walsh TJ, Hayden RT, Larone DH. 2018. Medically Important Fungi A Guide to Identification 6th ed. ASM Press, USA.

Wangge ESA, Suprapta DN, Wirya GNA. 2012. Isolasi dan identifikasi jamur penghasil mikotoksin pada biji kakao kering yang dihasilkan di Flores. J Agritech Sci Biotechnol 1 (1): 39-47.

Watanabe T. 2002. Pictorial Atlas of Soil and Seed Fungi Morphologies of Cultured Fungi and Key to Species 2nd Edition. CRC Press, Boca Raton, FL. 